\title{
Chytrid infections of Daphnia pulicaria: development, ecology, pathology and phylogeny of Polycaryum laeve
}

\author{
PIETER T. J. JOHNSON,$*$ JOYCE E. LONGCORE ${ }^{\dagger}$ DANIEL E. STANTON,$*$ RYAN B. CARNEGIE, ${ }^{\ddagger}$ \\ JEFFREY D. SHIELDS ${ }^{\ddagger}$ AND ERIC R. PREU* \\ ${ }^{*}$ Center for Limnology, University of Wisconsin, Madison, WI, U.S.A. \\ ${ }^{+}$Department of Biological Sciences, University of Maine, Orono, ME, U.S.A. \\ ${ }^{\ddagger}$ Virginia Institute of Marine Science, College of William and Mary, Gloucester Point, VA, U.S.A.
}

\section{SUMMARY}

1. We combined ecological surveys, life table studies, microscopy and molecular sequencing to determine the development, ecology, pathology and phylogeny of Polycaryum laeve, an endoparasite of cladocerans. We report the first records of $P$. laeve from North America, where we have used a polymerase chain reaction primer and microscopic examination to confirm infections in 14 lakes. Infections are highly pathogenic and caused increased mortality, reduced growth, and reproductive castration in Daphnia pulicaria during life table studies.

2. Biweekly data from Allequash Lake (Wisconsin, U.S.A.) throughout 2003 indicated that fecundity and infection prevalence were inversely correlated. Infection prevalence was highest in late winter and early spring (up to $80 \%$ ) and lowest during late summer. Epidemics were generally followed by sharp declines in host population density (up to 99\%). 3. Within the haemocoel of its host, P. laeve forms thick-walled sporangia, which occur systemically in later stages of infection. Fungal thalli associate closely with muscle fibres and connective tissue, leading to degeneration as the infection becomes advanced.

Following death of the host, flagellated zoospores are released through an exit papilla on the sporangium. Based on the infection-induced castration of the host and increases in infection prevalence with Daphnia size, we postulate that transmission is horizontal, but may be indirect through an additional host or free-living stage.

4. Molecular and morphological data clearly indicate that $P$. laeve belongs in the fungal phylum Chytriodiomycota, order Blastocladiales. Based on ribosomal RNA gene sequences and morphological features, we transfer the genus Polycaryum from the Haplosporidia to the Chytridiomycota, and designate a lectotype and epitype for $P$. laeve. Considering the high prevalence of $P$. laeve infection within Daphnia populations, the frequency with which we detected infections among lakes, and the keystone importance of large-bodied Daphnia in aquatic food webs, we suggest that $P$. laeve may exert a regulatory influence on Daphnia populations in lake ecosystems.

Keywords: Blastocladiales, Chytridiomycota, fungus, parasite, zooplankton mortality

Correspondence: Pieter Johnson, Center for Limnology, University of Wisconsin, 680 North Park Street, Madison, WI 53706-1492, U.S.A. E-mail: ptjohnson2@wisc.edu

\section{Introduction}

Freshwater cladocerans host a variety of ecto- and endoparasites, including viruses, bacteria, algae, microsporidians, haplosporidians, ciliates, fungi, oomycetes and helminths (reviewed in Green, 1974). Although many pathogens have a low prevalence in a 
given host population, some can achieve a high prevalence, often with substantial, population-level consequences for the hosts (Burns, 1989). Pathogenic effects include reduced growth rates, inhibited reproduction (including castration), and increased mortality, leading some researchers to suggest that parasites can regulate zooplankton populations (Brambilla, 1983; Ebert, Lipsitch \& Mangin, 2000; Bittner, Rothhaupt \& Ebert, 2002). Infection also may have indirect consequences. Infected zooplankton are often visually conspicuous (Willey, Cantrell \& Threlkeld, 1990; Willey, Willey \& Threlkeld, 1993) and may suffer reduced mobility or altered diel-vertical migration behaviour (Torgersen, Karlsbakk \& Kaartvedt, 2002; Fels, Lee \& Ebert, 2004), each of which may further increase the mortality caused by predation.

Research on diseases of cladocerans has focused primarily on European populations of Daphnia from shallow ponds and rock pools with simplified food webs (Ebert, 1995; Stirnadel \& Ebert, 1997; Bengtsson \& Ebert, 1998; Ebert et al., 2000; Ebert, Hottinger \& Pajunen, 2001; Decaestecker, De Meester \& Ebert, 2002). Few researchers have explored the importance of parasitic infection in Daphnia populations in lakes, particularly in North America. The few existing reports document an epidemic in a single or small number of lakes over a limited time. For example, Yan \& Larsson (1988) reported on the effects of microsporidian infections in Holopedium gibberum Zaddach, 1855 from a Canadian Shield lake during 1985. Similarly, Duffy et al. (2005) investigated the role of predation in controlling bacterial infections of Daphnia dentifera Taylor and Hebert, 1996 in Michigan lakes in 2003. Based on their observations, researchers in both studies suggested that pathogens had strong direct and indirect effects on host population dynamics. Given the keystone importance of Daphnia as grazers of phytoplankton and as a food resource for planktivorous fishes, pathogens that negatively affect the dynamics of Daphnia populations have the potential to significantly influence food webs, water clarity, and fish production in lakes.

During routine limnological sampling by the North Temperate Lakes Long-Term Ecological Research programme, we discovered high levels of infection ( $>50 \%$ prevalence) by an unusual parasite of Daphnia pulicaria Forbes, 1893 from Allequash Lake, Wisconsin. Infected animals were visibly conspicuous (Fig. 1$\mathrm{a}, \mathrm{b})$, often moribund, and rarely gravid, suggesting that the infection was pathogenic. Examination of archived zooplankton samples from Allequash revealed no evidence of infection in previous years (1982-2001). Comparison of the parasite with drawings and descriptions in Green (1974) suggested similarities with Polycaryum laeve Stempell, 1903, a presumed haplosporidian described by Stempell (1903) from preserved samples of Daphnia longispina Müller, 1785 collected in Germany. Green (1974) reported a second observation of this parasite in Daphnia pulex Leydig, 1860 from Greenland in 1961. However, neither author provided information on the ecology, pathology or life cycle of the parasite, nor are we aware of any other published accounts on $P$. laeve.

Here we present the first records of $P$. laeve infection in Daphnia populations from North America and describe the development, basic ecology, partial life cycle, pathology and phylogeny of this parasite. Our objectives were to (i) determine the effects of infection on individual hosts using life table studies and histopathology, (ii) evaluate the importance of epidemics for Daphnia populations using biweekly infection data from Allequash Lake, (iii) study the development and life cycle of $P$. laeve through microscopy and development of a polymerase chain reaction (PCR) primer specific to Polycaryum sp., and (iv) use morphological and molecular data to resolve the phylogenetic relationships of Polycaryum.

\section{Methods}

\section{Collection and processing of field samples}

Allequash Lake is a 172 ha lake located in Vilas County, Wisconsin $\left(46.041^{\circ} \mathrm{N}, 89.628^{\circ} \mathrm{W}\right)$. It is one of eleven lakes in the North Temperate Lakes LongTerm Ecological Research (LTER) programme run by the University of Wisconsin. Detailed information on the physicochemical and biological features of this lake is available at http://lter.limnology.wisc.edu. During the ice-free period of 2003 (April to November), we collected vertical zooplankton tows biweekly from the deepest point $(7 \mathrm{~m})$ of Allequash Lake with an $80 \mu \mathrm{m}$ Wisconsin plankton net. During winter months (December to March), samples were collected monthly or as ice conditions permitted. Samples were preserved immediately in $80 \%$ ethanol and subsequently inspected for infection with a stereomicroscope. For each sample, we examined a minimum of 

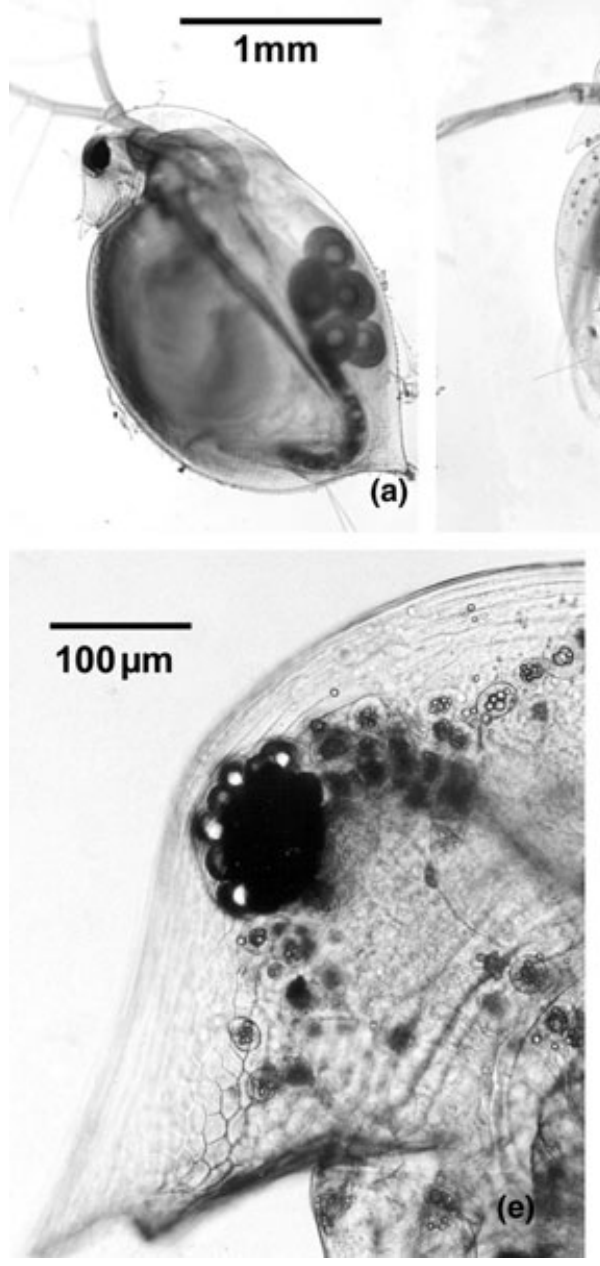

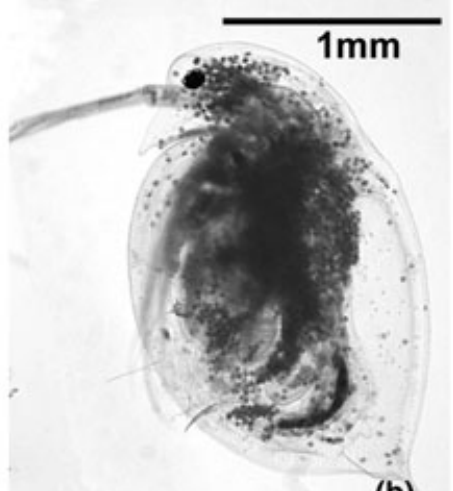

(b)

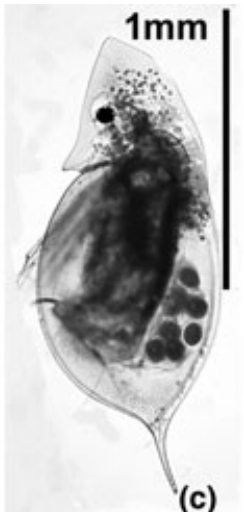

(c)

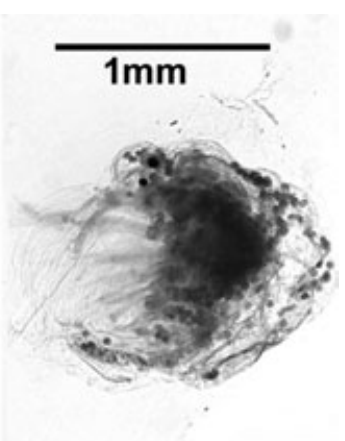

(d)
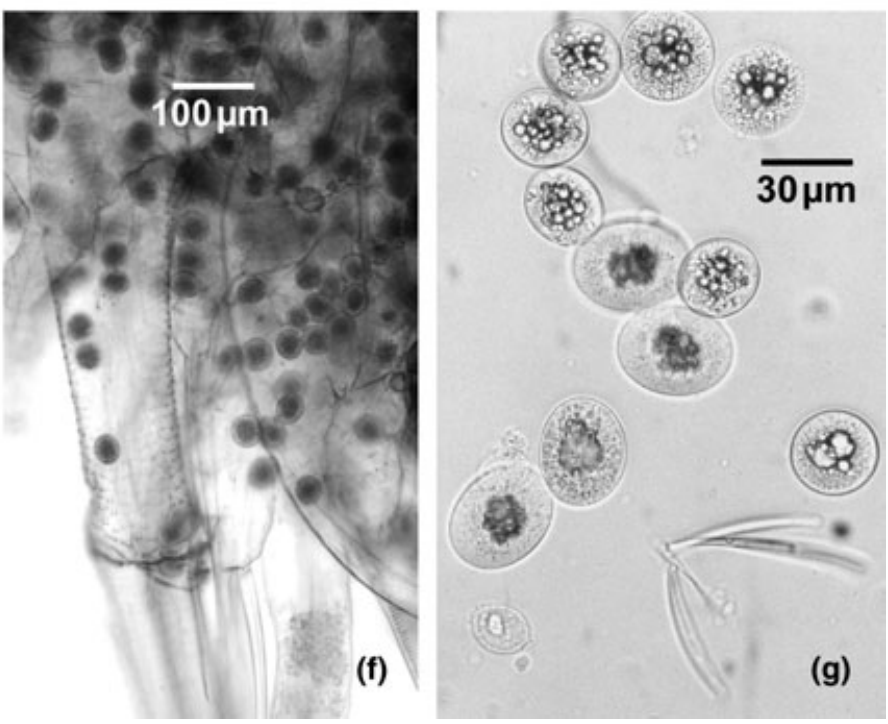

Fig. 1 (a) Healthy, gravid adult Daphnia pulicaria. (b) Daphnia with a severe Polycaryum laeve infection exhibiting numerous chytrid sporangia in the haemocoel. (c) Infected D. galeata mendotae with eggs in the brood chamber. (d) Infected Holopedium gibberum. (e) Head view of infected D. pulicaria. (f) Infected D. pulicaria showing thalli in front appendages. (g) Polycaryum laeve thalli freshly removed from $D$. pulicaria.

200 mature $(>1.2 \mathrm{~mm})$ female D. pulicaria. Infected animals were isolated, measured with an ocular micrometer, and ranked for intensity of infection. Intensity was based on a semi-quantitative estimate of the density of chytrid sporangia in an infected individual: $0=$ no infection, $1=$ light infection $(1-500$ sporangia), 2 = moderate infection (501-1000), and $3=$ severe infection $(>1000)$. We calibrated these intensity estimates by dissecting representative Daphnia and counting sporangia. The mean size of uninfected $D$. pulicaria was determined from measurements of 50 or more randomly selected adults. We also quantified the percentage of adult females with eggs, the number of eggs per gravid female, and the abundance of other cladocerans (e.g. D. mendotae Birge 1918 and H. gibberum). To obtain additional material for validating the specificity of PCR primers, we collected zooplankton from 14 lakes in which $P$. laeve had been identified visually and six lakes from which no infection was observed.

\section{Development and microscopy}

We examined a range of infected D. pulicaria to evaluate the development of $P$. laeve. Living or recently dead infected Daphnia were isolated and dissected under a stereomicroscope. We examined morphological features at different developmental stages of the parasite with light and electron microscopy. To examine zoospores and their release by mature sporangia, we disrupted the carapace of heavily infected, recently dead or dying Daphnia and 
placed them at $5{ }^{\circ} \mathrm{C}$. After $24-48 \mathrm{~h}$, sporangia with well-developed exit pores and abundant zoospores were usually present.

For histology, we fixed whole D. pulicaria in $10 \%$ neutral-buffered formalin or Bouins solution. Samples were decalcified for $2 \mathrm{~h}$ using the formic acid-sodium citrate method, then processed through routine paraffin procedures using Harris haematoxylin and eosin Y (e.g. Luna, 1968; Humason, 1979). Tissues were examined with an Olympus BX51 compound microscope equipped with a Nikon DXM1200 and ACT-1 image capture program (Nikon, Melville, NY, U.S.A.).

For scanning electron microscopy, we fixed Daphnia tissues or isolated sporangia in $2.5 \%$ glutaraldehyde buffered in artificial pond water $\left(1 \mathrm{mM} \mathrm{KH}_{2} \mathrm{PO}_{4}\right.$, $0.1 \mathrm{mM} \mathrm{MgCl} 2,0.02 \mathrm{mM} \mathrm{CaCl}_{2}$ ) overnight at $4{ }^{\circ} \mathrm{C}$ and post-fixed tissues for $1 \mathrm{~h}$ in $1 \% \mathrm{OsO}_{4}$. Material was then dehydrated through an ethanol series and critical point dried. Specimens were coated with approximately $20 \mathrm{~nm} 60$ : 40 gold : palladium (See Vac Autoconductavac sputter coater, Pittsburgh, PA, U.S.A.) and observed with a Hitachi S-570 scanning electron microscope. For transmission electron microscopy, samples were primary fixed in Karnovsky's fixative, post-fixed in $\mathrm{OsO}_{4}$, and dehydrated through a graded ethanol series. Samples were infiltrated and embedded in Spurr's low viscosity resin. Ultra-thin sections were collected and viewed on a JEOL 100CX (Peabody, MA, U.S.A.) at $80 \mathrm{kV}$. Images were captured using a SIS MegaView III (Lakewood, CO, U.S.A.).

We unsuccessfully attempted to isolate $P$. laeve into pure culture on various chytrid media including PmTG, (Barr \& Désaulniers, 1987) and mTGh (tryptone, $8 \mathrm{~g} \mathrm{~L}^{-1}$; gelatin hydrolysate, $2 \mathrm{~g} \mathrm{~L}^{-1}$ ) and a medium for growing insect tissue (Grace's insect medium and crayfish saline, with and without added FBS).

\section{Pathology}

To evaluate the effects of $P$. laeve infection on host survival, growth, and reproduction, we conducted a life table experiment with $D$. pulicaria from Tenderfoot Lake, Vilas County, Wisconsin. We randomly selected 30 infected and 30 uninfected Daphnia and recorded the size, infection intensity, and fecundity of each individual. Initial sizes $\pm 1 \mathrm{SE}$ of infected and uninfected Daphnia were $1.88 \pm 0.05$ and $1.87 \pm 0.05$, respectively. Daphnia were isolated individually into
$50 \mathrm{~mL}$ containers and acclimated to artificial lake water (COMBO; Kilham et al., 1998) over 24 h. Individuals that died prior to initiation of the experiment were replaced. Daphnia were maintained on a $16: 8 \mathrm{~h}$ light : dark cycle at $18 \pm 2{ }^{\circ} \mathrm{C}$. Every other day, Daphnia were transferred into new containers filled with clean water and $1 \mathrm{~mL}$ of a Scenedesumus solution (approximately $6.5 \times 10^{4}$ cell count). Containers were autoclaved before re-use. We recorded the numbers of offspring and moults produced between water changes. Dead individuals were measured and examined to evaluate infection status and intensity before preservation. We concluded the experiment when all of the infected individuals had died.

\section{Sequencing}

DNA extraction. Moderately to heavily infected D. pulicaria from Birch Lake (Vilas County, Wisconsin) were fixed in 95\% ethanol for molecular analyses; uninfected individuals were fixed separately. DNA was extracted from two pools of ten infected and two pools of five uninfected D. pulicaria using a QIAGEN (Valencia, CA, U.S.A.) DNeasy Tissue Kit according to the manufacturer's instructions and with a final elution in $50 \mu \mathrm{L}$ Buffer AE. Small sub-unit (SSU) rDNA was amplified using a protocol designed for amplification of protistan and fungal sequences from metazoan hosts (see Carnegie et al., 2003; Bower et al., 2004 for reaction conditions). Amplification products from the presumptive Polycaryum sp. were excised from the gel, purified using a S.N.A.P. Gel Purification Kit (Invitrogen, Carlsbad, CA, U.S.A.), and cloned using a TOPO TA Cloning Kit (Invitrogen). Products were sequenced on a LICOR 4200 following a sequencing reaction with vector-specific (M13 forward and reverse) primers and compared against the GenBank database using the BLAST search algorithm.

Polymerase chain reaction probes. We designed PCR primers that were presumptively specific to Polycaryum sp. to (i) verify correspondence between the visual identification of infection and the molecular signal and (ii) screen for additional stages or hosts of the parasite. We selected primers Polycaryum-F1 (5'-TAGTCGAACCTCAAGAGCG-3') and Polycaryum-R2 (5'-CGGCATCGTTTATGGTTGTG-3') from among several candidates for continued application. DNA for presumptive Polycarum sp.-specific PCR was 
obtained from numerous sources: lake sediment, lake seston (filtered onto a $0.2 \mu \mathrm{m}$ glass fibre filter), calanoid and cyclopoid copepods, Chaoborus larvae and D. pulicaria from lakes with visually-identified infections [Allequash, Katinka, Nelson, Oxbow, Horsehead, Crab, Annabelle, Tenderfoot, Big Muskellunge, South Turtle, Spider (all in Vilas County), Owen (Bayfield County), Nebagamon (Douglas County), and Devils (Sauk County)] and lakes without discernible infection [Crystal, Stormy (Vilas County), Lulu, Beulah, Green (Walworth County), and Ripley (Jefferson County)]. One microliter $(1 \mu \mathrm{L})$ of template DNA was used in $25-\mu \mathrm{L}$ PCR reactions that also included 1X PCR Buffer, $\mathrm{MgCl}_{2}$ at $1.5 \mathrm{~mm}$, each dNTP at $0.2 \mathrm{mM}$, primers Polycaryum-F1 and R2 at $0.5 \mu \mathrm{M}$, and Taq polymerase at 0.08 units $\mu \mathrm{L}^{-1}$ (all purchased from Invitrogen). Control reactions included either Polycaryum-positive D. pulicaria DNA from Birch Lake (positive) or $\mathrm{ddH}_{2} \mathrm{O}$ (negative). Cycling in an $\mathrm{MJ}$ Research PTC-200 thermal cycler began with denaturation at $95{ }^{\circ} \mathrm{C}$ for $7 \mathrm{~min}$, continued with 40 cycles of $95{ }^{\circ} \mathrm{C}$ for $1 \mathrm{~min}, 58.9{ }^{\circ} \mathrm{C}$ for $1 \mathrm{~min}$, and $72{ }^{\circ} \mathrm{C}$ for $1 \mathrm{~min}$ and ended with a final extension at $72{ }^{\circ} \mathrm{C}$ for $7 \mathrm{~min}$. Products were electrophoresed in a $1.5 \%$ agarose (in 1X TBE) gel, post-stained with ethidium bromide, and visualised under UV light.

Phylogeny. A nucleotide BLAST search of the ribosomal sequence suggested a close homology to Catenaria anguillulae (Chytridiomycota, Blastocladiales). This preliminary information enabled a more thorough and directed phylogenetic analysis using available sequences of members of Blastocladiales as well as a wide range of other fungal taxa. All other sequences were obtained from GenBank: Allomyces arbuscula (AY55254), Allomyces macrogynus (U23936), Ascobolus lineolatus (L37533), Blastocladiella emersonii (AY635842), C. anguillulae (AF164339), Catenophlyctis sp. JEL298 (AY635822), Coelomomyces stegomyiae (AF322406), Cronartium ribicola (M94338), Gigaspora albida (Z14009), Microallomyces sp. CR74 (AY635840), Neocallimastix sp. LM-2 (M59761), Neolecta vitellina (Z27393), Orbilia delicatula (U72603), Peridermium harknessii (M94339), Peziza badia (L37539), Physoderma maydis (AY601708), Pneumocystis carinii (L27658), Saccharomyces cerevisiae (J01353), Schizosaccharomyces pombe (X54866), Spizellomyces acuminatus (M59759), Sporobolomyces roseus (X60181), Taphrina wiesneri (D12531), Tilletia caries (U00972), Ustilago hordei
(U00973), Zoophagus insidians (AB016009), Zoophthora radicans (D29949). Sequences other than those from $P$. laeve were aligned using MacClade v4.05 (Maddison \& Maddison, 2002) and analysed with PAUP* v4.0b10 (Swofford, 2002).

To mitigate the biases inherent in each algorithm, we used two analyses to explore the phylogenetic position of Polycaryum. A maximum parsimony (MP) heuristic search was conducted with 1000 random addition replicates with tree branch reconnection (TBR) branch swapping, equal character weighting, MULTREES activated and steepest descent option not activated. A Bayesian heuristic search was also conducted with MrBayes v3.1 (Huelsenbeck \& Ronquist, 2001). Four replicates of four chains were run for 1000000 generations (nst $=6$, rates $=$ gamma, savebrlens $=$ yes, bur$\operatorname{nin}=100$ 000, heat $=0.2$ ). Trees were sampled every 100 generations. To better resolve relationships within the order, we constructed an additional tree within the clade Blastocladiales using a MP search (settings as above) and a reduced data set (nine member taxa and one outgroup).

\section{Results}

\section{Ecological observations}

We observed individuals of $D$. pulicaria from Allequash Lake infected with $P$. laeve on all but two sample dates in 2003 (Fig. 2a). Prevalence of infection in mature D. pulicaria, however, varied considerably among seasons, from a maximum prevalence in March $(>80 \%)$ to a minimum in late summer $(<1 \%$; Fig. 2b). The highest infection levels occurred between January and March when the lake's surface was frozen. The population density of $D$. pulicaria subsequently declined by two orders of magnitude before recovering in early June (Fig. 2a).

Infection prevalence increased linearly as a function of Daphnia size (Fig. 3a) and hosts with discernable $P$. laeve infection were significantly larger than uninfected individuals (Fig. 3b; $P<0.0001$, ANOVA, $F=$ 107.251; $N=2306$ ). Immature $D$. pulicaria were rarely infected. On average, larger infected Daphnia also exhibited more severe infections than smaller infected individuals $(P<0.0001 ; r=0.242, N=1454)$. Infection was negatively associated with host fecundity $\left(P<0.0001 ; \quad \chi^{2}=565.416 ; \quad N=2306\right)$. Only five $(0.35 \%)$ infected D. pulicaria contained eggs, indicating 

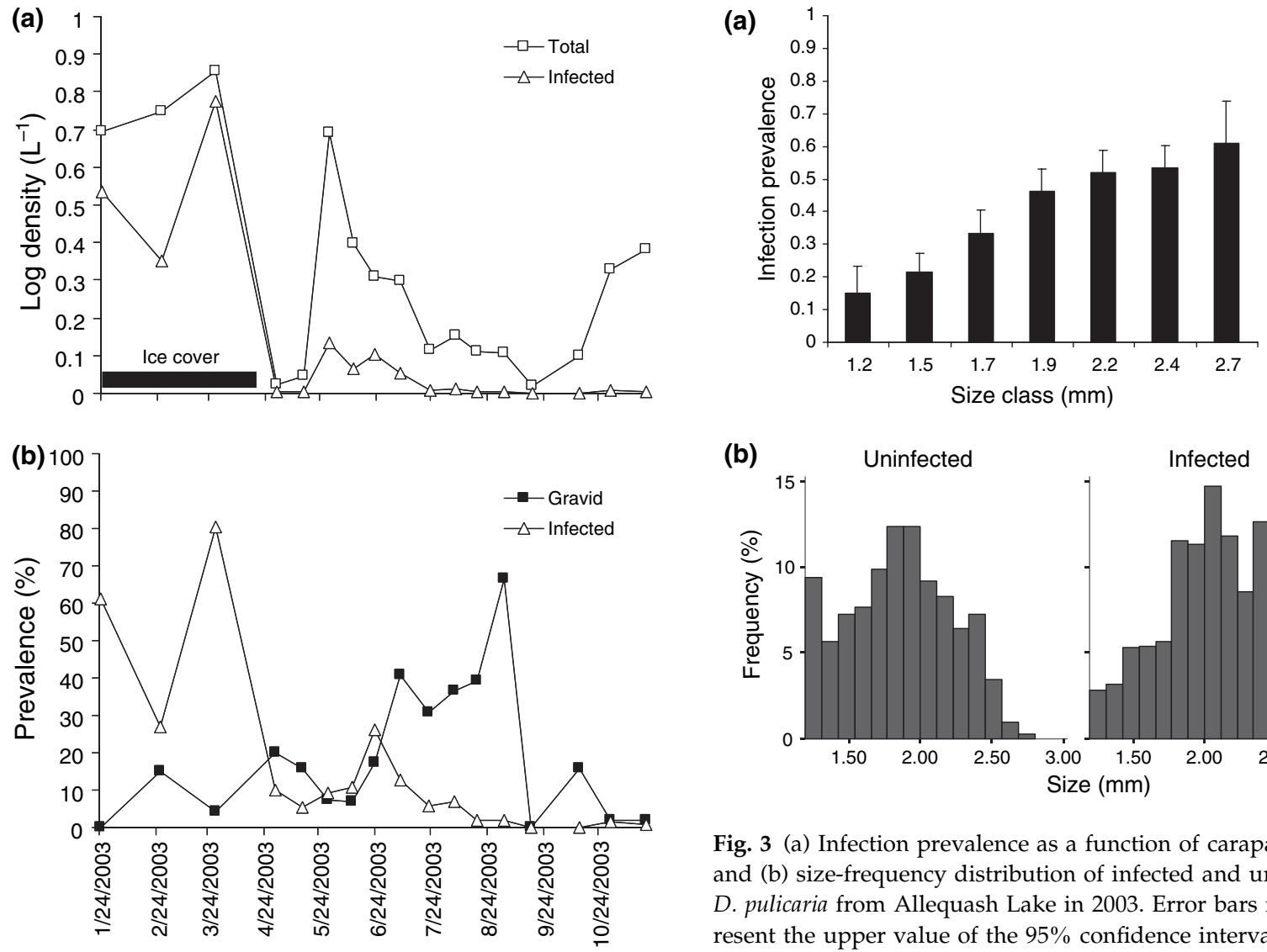

Fig. 2 Temporal patterns in (a) the density (logarithmicallytransformed) of $D$. pulicaria infected with $P$. laeve and the total D. pulicaria population density and (b) the percentages of gravid (egg-bearing) and infected Daphnia. All data are from Allequash Lake, Vilas Co., Wisconsin. Black bar indicates the period of time in which the lake was frozen.

that infection castrated the host. Correspondingly, the percentage of fecund hosts was low during epidemics (Fig. 2b).

We observed $P$. laeve infection in other species of zooplankton only rarely. Throughout 2003, only 15 D. galeata mendotae were found infected (Fig. 1c; $N=$ $2683)$. Four of these $(26.7 \%)$ supported eggs, suggesting the infection was less pathogenic in this species than in D. pulicaria $\left(P<0.001, \chi^{2}=132.41 ; N=1455\right)$. One infected $H$. gibberum was also observed ( $N>>1000$; Fig. $1 d$ ).

\section{Development and life cycle}

The haemocoel of infected Daphnia individuals was filled with between 50 and 2500 spherical sporangia,

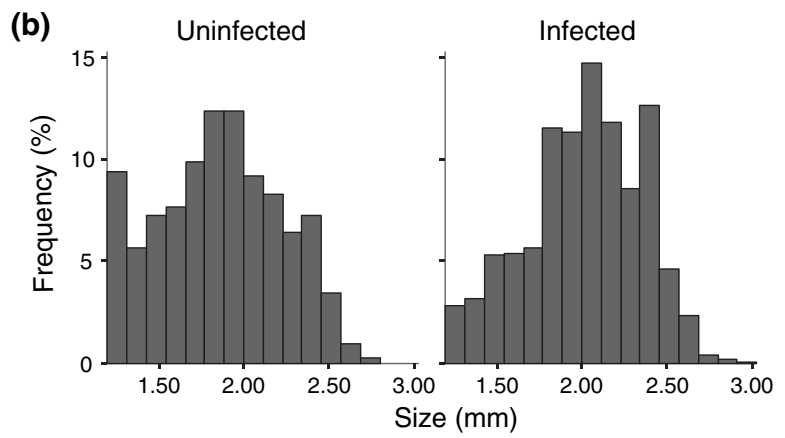

Fig. 3 (a) Infection prevalence as a function of carapace size and (b) size-frequency distribution of infected and uninfected D. pulicaria from Allequash Lake in 2003. Error bars in (a) represent the upper value of the $95 \%$ confidence interval for proportions.

depending on the intensity of infection. Infections were initially observed on and around the heart and subsequently in the head. In severe infections, sporangia occurred throughout the host body cavity and into the feeding and swimming appendages, causing a markedly altered appearance (Fig. 1b,c). The distribution and distinctive appearance of these sporangia made infection rapidly identifiable in both living and preserved samples. Dissection and subsequent enumeration of sporangia within 15 randomly selected, obviously infected Daphnia yielded an average ( $\pm 1 \mathrm{SE}$ ) of $920.9 \pm 91.3$ sporangia per host.

Dissection of infected Daphnia revealed many of the life history stages described by previous authors (Stempell, 1903; Green, 1974). We followed Stempell's (1903) division of development into seven growth stages and a sporulation stage. In stages I-III, from first appearance to final size (approximately $30 \mu \mathrm{m}$ ), thalli are characterised by the absence of a visible cell wall, as revealed by light microscopy (Fig. 4a-c), TEM (Fig. 5a,b) and histological preparations (Fig. 6c). The 

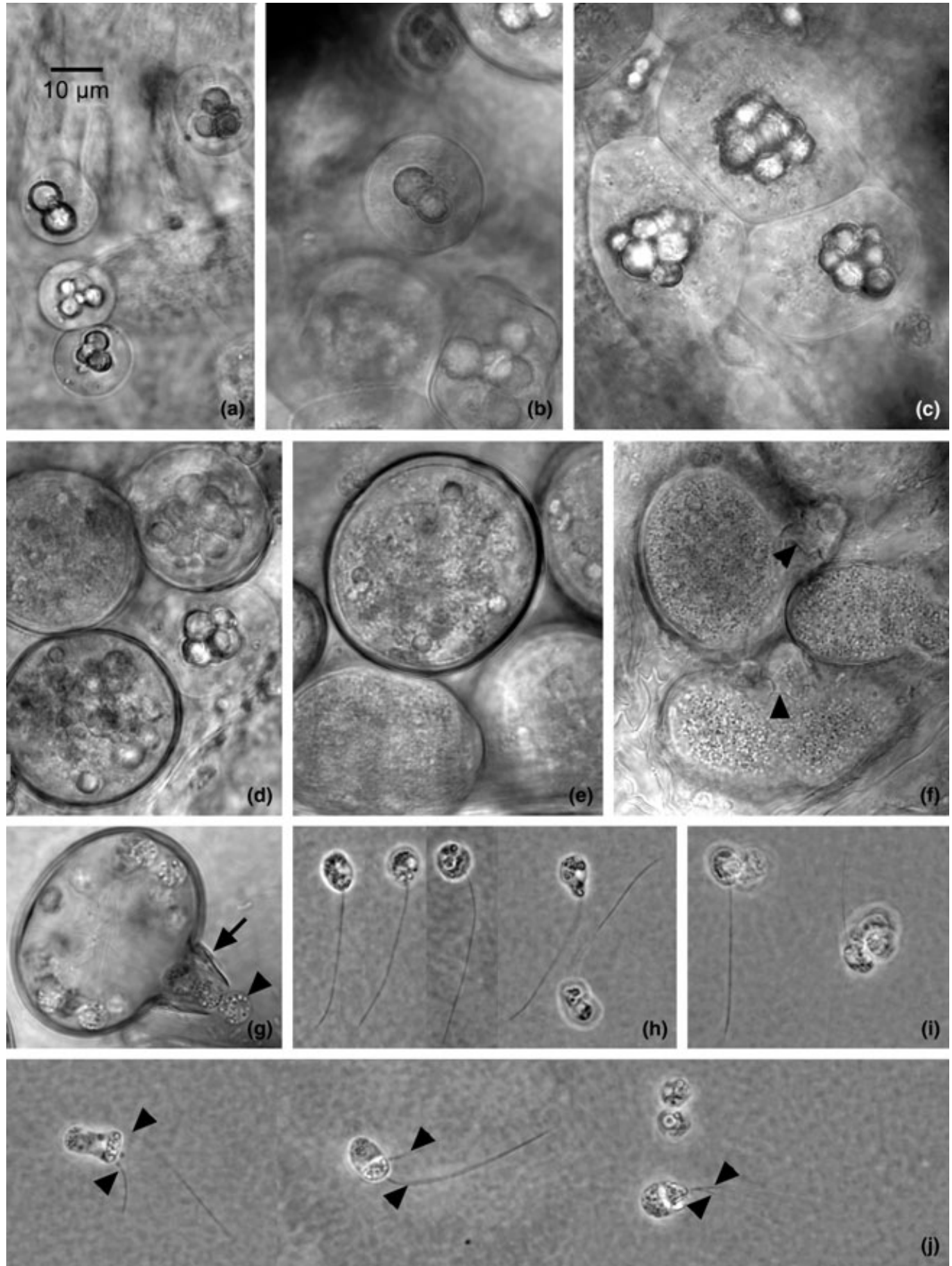

Fig. 4 Light microscopy of stages of development of Polycaryum laeve. (a) Smallest determined size class of thalli within living host. (b) Intermediate-sized thalli and (c) large thalli without visible walls. All developing thalli were recognisable by the accumulation of lipid globules in the core of the thallus. (d) Early walled thalli, with lipid globules smaller and more dispersed. (e) Increased number of smaller globules throughout spherical thallus. (f) Ovate and lobate zoosporangia. Membrane-covered sporangium has broken through wall of thallus leaving torn wall (arrow heads). (g) Open sporangium with exiting zoospore (arrowhead). Arrow shows edge of wall. (h) Montage of five zoospores, each with a posterior flagellum (i) Clumping of zoospores. (j) Montage of three biflagellate zoospores. Arrowheads indicate flagella. 

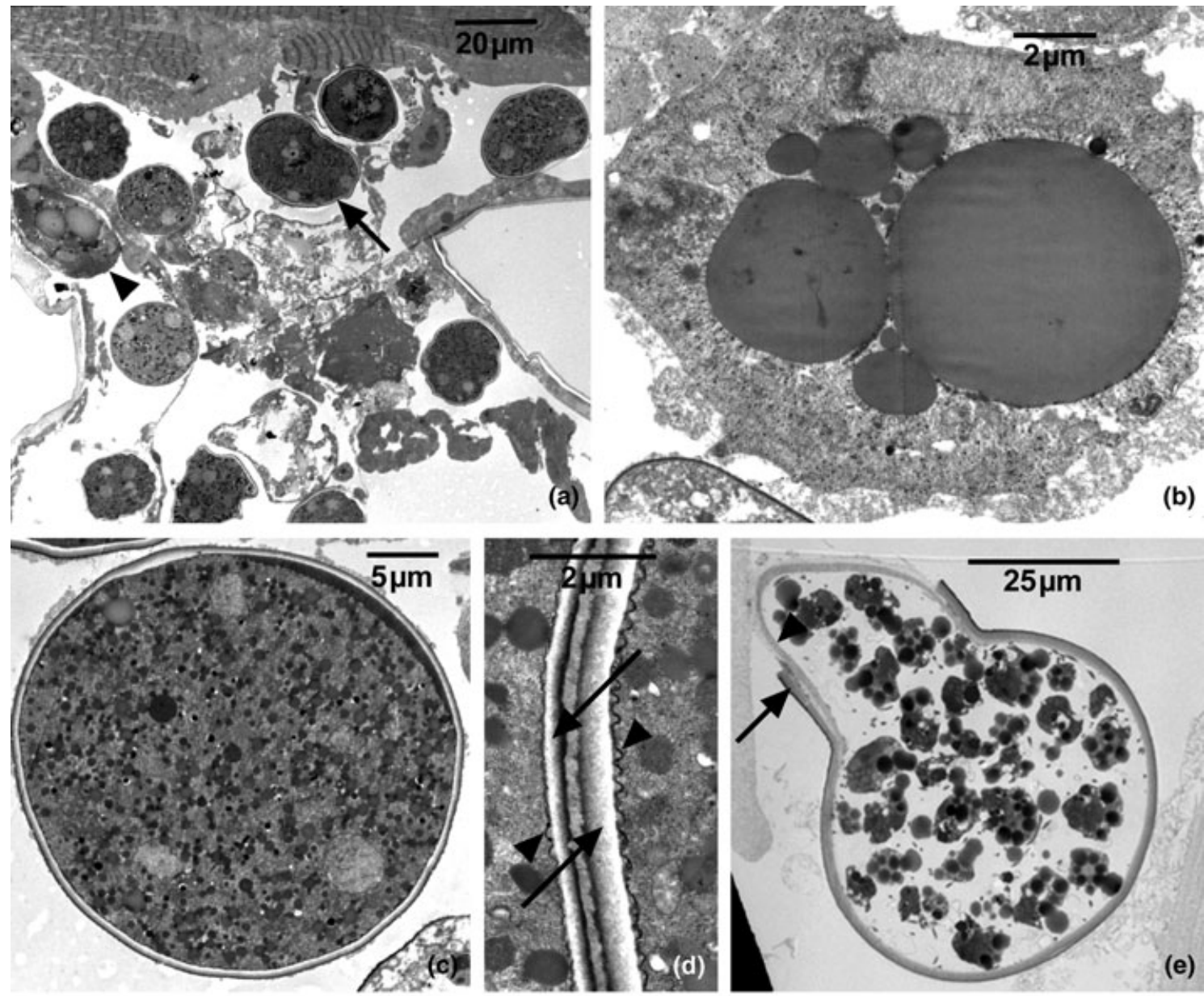

(e)
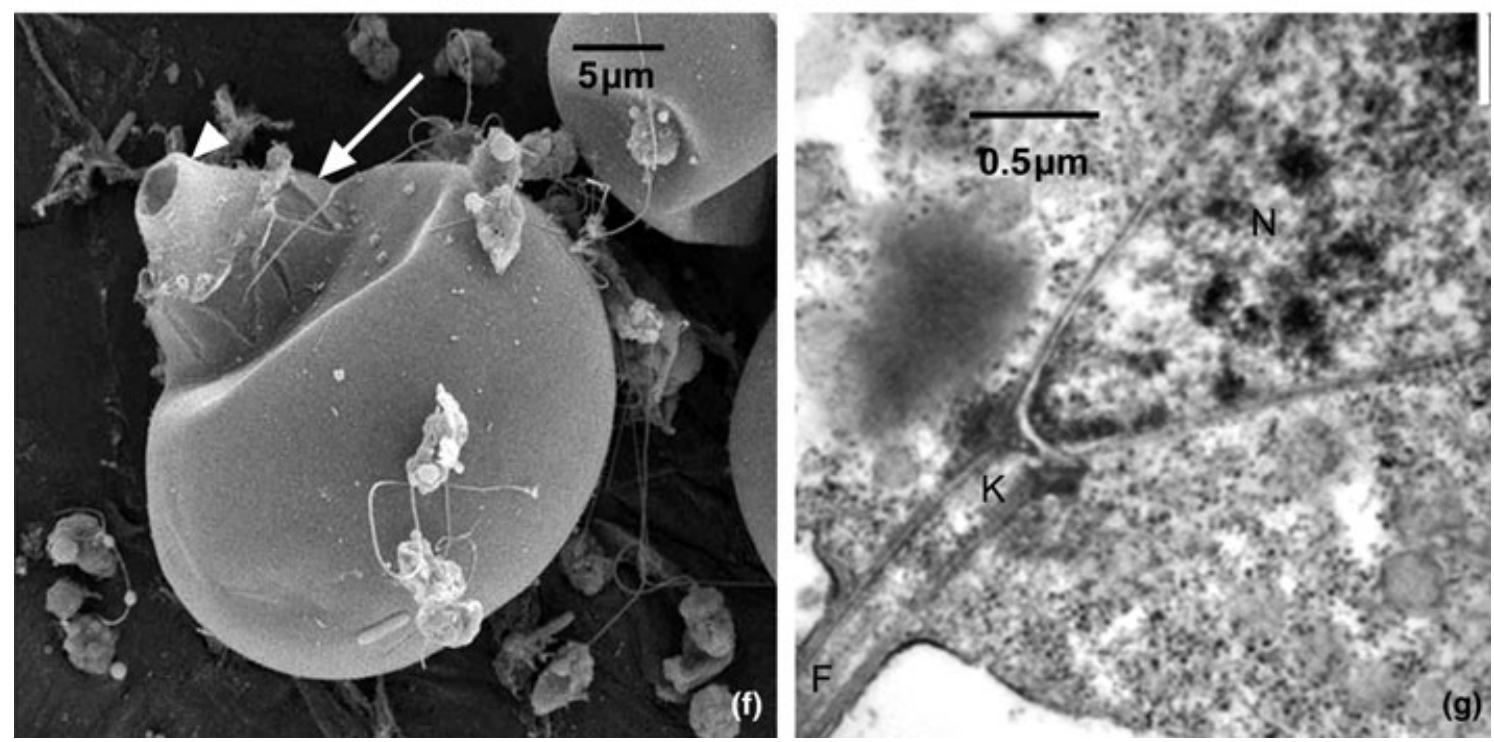

Fig. 5 Electron micrographs of P. laeve. (a) Unwalled and walled stages. (b) Unwalled thallus with central lipid globules. (c) Spherical walled stage. (d) Abutting walls of thalli (arrows) with membranes (arrowheads) just inside of the walls. (e) Section of mature zoosporangium containing cleaved zoospores. Arrow indicates edge of wall; arrowhead indicates membrane of emerging papilla. (f) SEM view of empty zoosporangium. Arrow indicates torn wall; arrowhead indicates emerged papilla. (g) Longitudinal section of basal part of zoospore; $\mathrm{N}$ = nucleus, which is proximal to the kinetosome (k). The flagellum (f) extends from the kinetosome. 

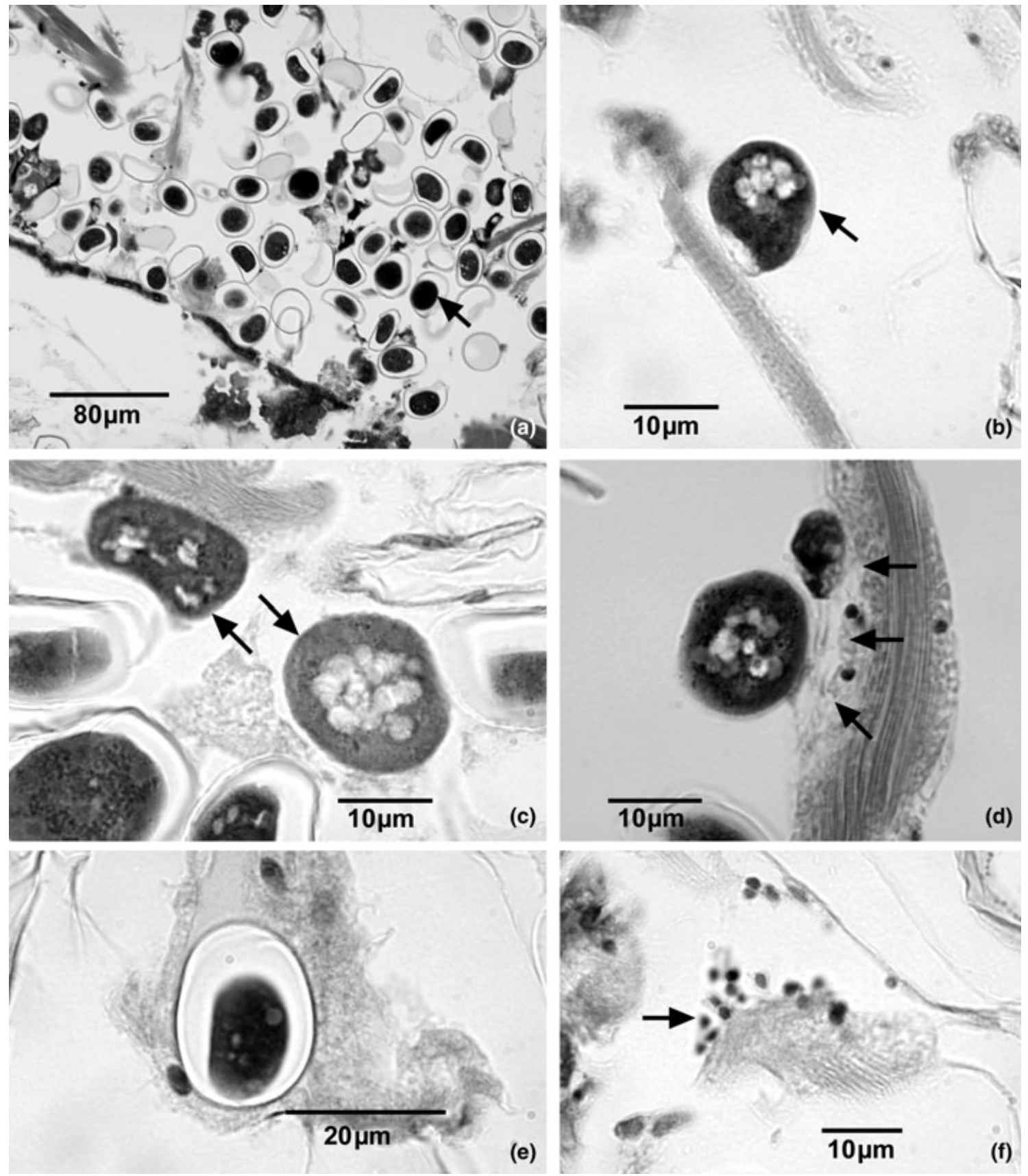

Fig. 6 Histological preparations of P. laeve in D. pulicaria. (a) Systemic infection with stage VI-VII sporangia (arrow) showing the loss or degeneration of muscle fibres and connective tissues; L, gut lumen. (b) Young thallus (arrow) in early stages of development associated with a muscle fibre. (c) Stage IV-V sporangia (arrows) closely associated with muscle and connective tissues. (d) Stage III-IV sporangium associated with a vacuolated, hypertrophied muscle fibre. Note the vacuolated area (arrows) of the muscle adjacent to the thalli. (e) Stage VI-VII sporangium from a late-stage infection within or adhering to connective tissues. (f) Haemocyte aggregate (arrow) in the haemolymph of an infected host.

earliest stages were difficult to observe and were seen primarily in lightly infected individuals. A central clustering of lipid globules characterised both early unwalled stages (Fig. 4a) and later walled stages
(Stage IV, Figs 1e \& 1g) of fungal thalli within living Daphnia. Before cell wall formation, thalli tended to be flattened (Fig. 4b,c; Fig. 5a,b); once walls were visible, however, thalli appeared round (Fig. 4d,e; Fig. 5c). 
Some walled thalli were irregularly lobate (Fig. 4f). Thalli walls varied in thicknesses (Fig. $5 \mathrm{~d}$ ) and were underlain by a membrane (Fig. $5 \mathrm{~d}-\mathrm{f}$ ), which emerged through the wall during sporulation.

Sporulation. Zoosporogenesis occurred following disruption of the carapace of dead or dying Daphnia. Stages $\mathrm{V}$ and VI (Fig. 4e,f) were precursors of sporulation and represented stages of internal reorganisation, during which the lipid bodies were redistributed and zoospores were formed. During this reorganisation, an exit papilla formed, either in conjunction with protrusion of the thallus wall (Fig. 5e), or through rupture of the cell wall with the sporangial membrane emerging through the jagged opening (Fig. 4f). Motile zoospores (Fig. 4h) began to exit sporangia usually within $48 \mathrm{~h}$ after the disruption of the host carapace when incubated at $5{ }^{\circ} \mathrm{C}$. Motile spores were $5 \times 7 \mu \mathrm{m}(n=12)$ with a approximately $34 \mu \mathrm{m}$ flagellum (Fig. $4 \mathrm{~h}$ ). The kinetosome (basal body) of the zoospore flagellum is proximal to the cone-shaped nucleus (Fig. $5 \mathrm{~g}$ ), similar to those found in members of the Blastocladiales (Barr, 1990). After several hours of motility, zoospores lost their flagellum and encysted on whatever substrate was available. Zoospores sometimes joined together (Fig. 4i), and the presence of biflagellate spores (Fig. 4j) suggests that fusion may have occurred (i.e. zoospores are isogametes). A larger, multiflagellated stage was observed only infrequently.

Attempts to infect $D$. pulicaria with free-swimming zoospores were unsuccessful, despite treatments involving different clones and ages of Daphnia, variable temperatures, variable light regimes and different water mixtures. Individual thalli kept in sterile pond water augmented with penicillin and streptomycin $\left(0.5 \mathrm{mg} \mathrm{ml}^{-1}\right.$ each) developed somewhat but our efforts to culture $P$. laeve sporangia or zoospores on artificial media were unsuccessful.

\section{Pathology}

Histopathology. Early stages of infection associated closely with - but did not penetrate into - muscle fibres and connective tissue cells (Fig. 6a-d). Although rhizoids were not observed, early development stages, which had poorly defined protoplasmic regions, closely adhered to host tissues (Fig. 6b,d). As the cell walls of the sporangial thalli developed, many sporangia no longer adhered to muscle fibres, but some remained associated with muscle or connective tissues (Fig. 6c). Connective tissue cells that surrounded muscle fibre bundles with associated sporangia sometimes appeared hypertrophied or vacuolated (Fig. 6d). Degeneration and loss of muscle fibres and connective tissues were apparent in moderate and heavy infections. Heavy infections were systemic; sporangia occurred throughout the haemocoel and in some cases were surrounded by remnant muscle fibres or connective tissues (Fig. 6e). In moderate and heavy infections, haemocytic infiltrates were occasionally observed either surrounding a sporangium or as aggregates in the haemolymph (Fig. 6f). Further, the connective tissues contained no reserve inclusion cells, suggesting that infected animals lacked metabolic reserves and starved. Histologically, heavily infected hosts lacked significant gonadal development, but the sample size was relatively small $(n=12$ infected animals).

Life table. The life table study ended after 42 days, by which time all of the infected $(n=30)$ and 26 of 30 uninfected Daphnia had died. Within the infected group, infections became more severe over time and no individuals recovered from infection. One putatively uninfected Daphnia developed a visible infection during the study and was excluded from analyses. Infected and uninfected Daphnia differed significantly with respect to growth, survival, and reproduction. Infected individuals died sooner (12 \pm 2.21 days) than uninfected individuals (26 \pm 2.04 days; Fig. 7a; Kaplan-Meier Survival Analysis; $P<0.0001$; Log Rank = 28.46). By day 17, only $20 \%$ of infected Daphnia remained alive, whereas $>70 \%$ of the uninfected individuals were alive (Fig. 7a). Differences in reproduction were similarly extreme. Uninfected Daphnia produced, on average, $0.901 \pm 0.074$ offspring day $^{-1}$ and a cumulative total of 852 offspring. Infected Daphnia completely failed to reproduce (Fig. $7 \mathrm{~b} ; P<0.0001 ; F=147.823$ ). One infected individual produced a single clutch of eggs but no viable offspring were released. Although there were no differences between the initial lengths of each group (ANOVA, $P=0.953 ; F=0.003 ; N=60$ ), uninfected Daphnia moulted more frequently and grew significantly more than infected individuals during the course of the study (Fig. 7c; MANOVA; Wilks' $\lambda=49.333 ; \quad P<0.0001$; growth: $F=5.572$; $P=0.022$; moults: $F=27.453 ; P<0.0001)$. 
644 P.T.J. Johnson et al.
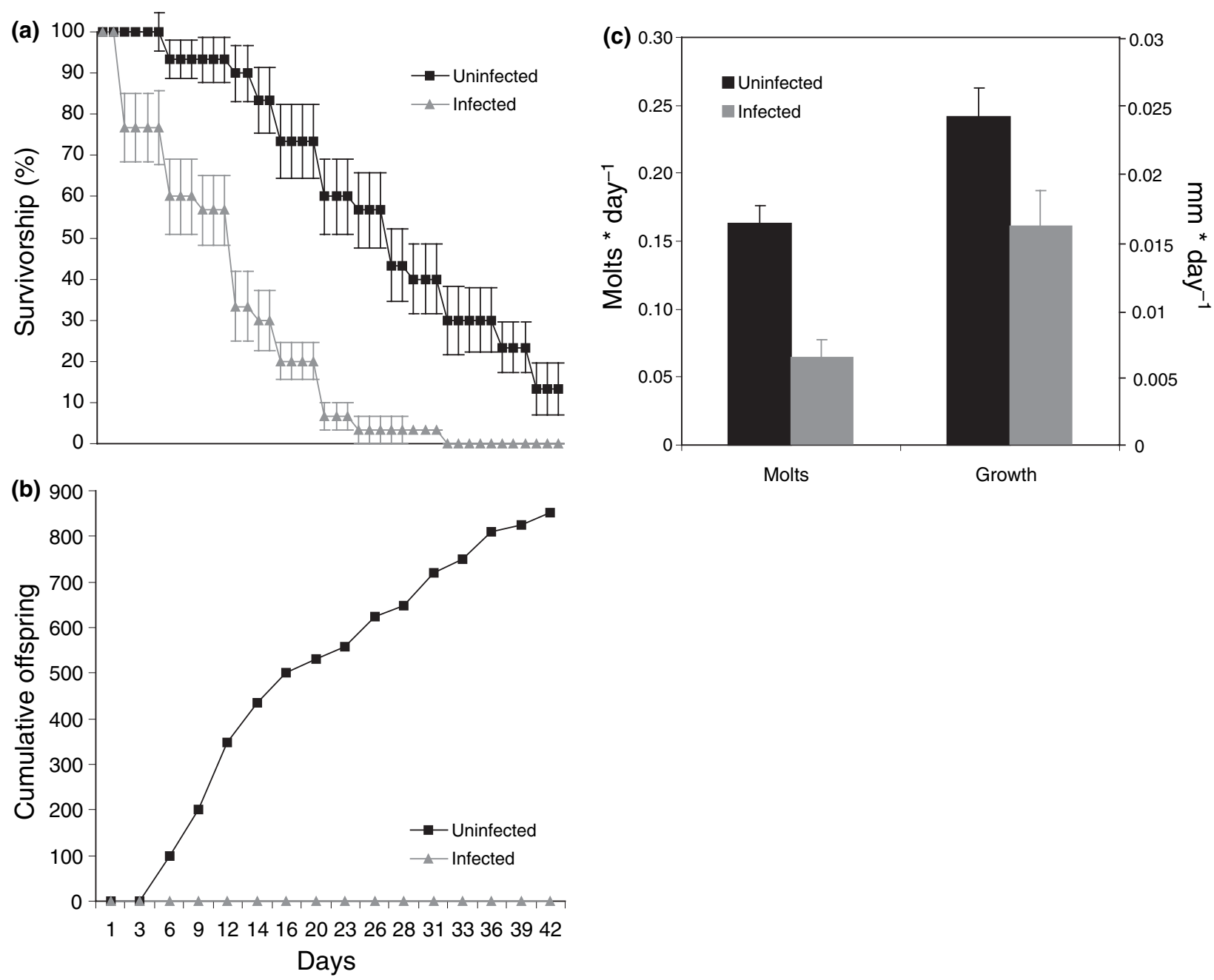

Fig. 7 (a) Survival, (b) cumulative reproductive output and (c) growth of infected and uninfected D. pulicaria from life table studies. Growth is measured both as the production of moults and change in carapace size (mm). Error bars represent \pm 1 SE.

\section{Sequencing and phylogeny}

Polymerase chain reaction amplification with the $581 \mathrm{~F} / 1134 \mathrm{R}$ primer pair yielded a pair of products; one $>1000 \mathrm{bp}$ product occurred in all $D$. pulicaria samples and the other, a 500-600 bp product, occurred only in infected hosts. We cloned and sequenced the latter product. In a BLAST search the 559-bp product was most similar to that of organisms in the order Blastocladiales (Fungi; Chytridiomycota). The PCR reaction specific for this sequence always yielded amplification from $D$. pulicaria individuals with gross signs of infection, but only occasionally from $D$. pulicaria not displaying gross signs.

Infected hosts from the 14 lakes, which were identified by microscopy to support infection, were also positive with the PCR primer set for P. laeve. None of the six lakes without obviously infected hosts yielded a positive PCR amplification. In the PCR-based search for $P$. laeve in the environment, cyclopoid copepods and Chaoborus larvae from Tenderfoot Lake were negative, but a pooled sample of 10-20 cyclopoid copepods from Devil's Lake was PCR-positive. A subsequent Chaoborus larva from Tenderfoot Lake was PCR-positive, as were samples of lake seston and 10-20 pooled cyclopoid copepods from Allequash Lake.

All phylogenetic analyses concurred strongly in placing $P$. laeve as a member of the order Blastocladiales (Fig. 8). The consensus of the Bayesian 50\% majority rule tree and the two most parsimonious trees (score $=1193$, parsimony informative characters $=264)$ are shown in Fig. 8. Within the order 


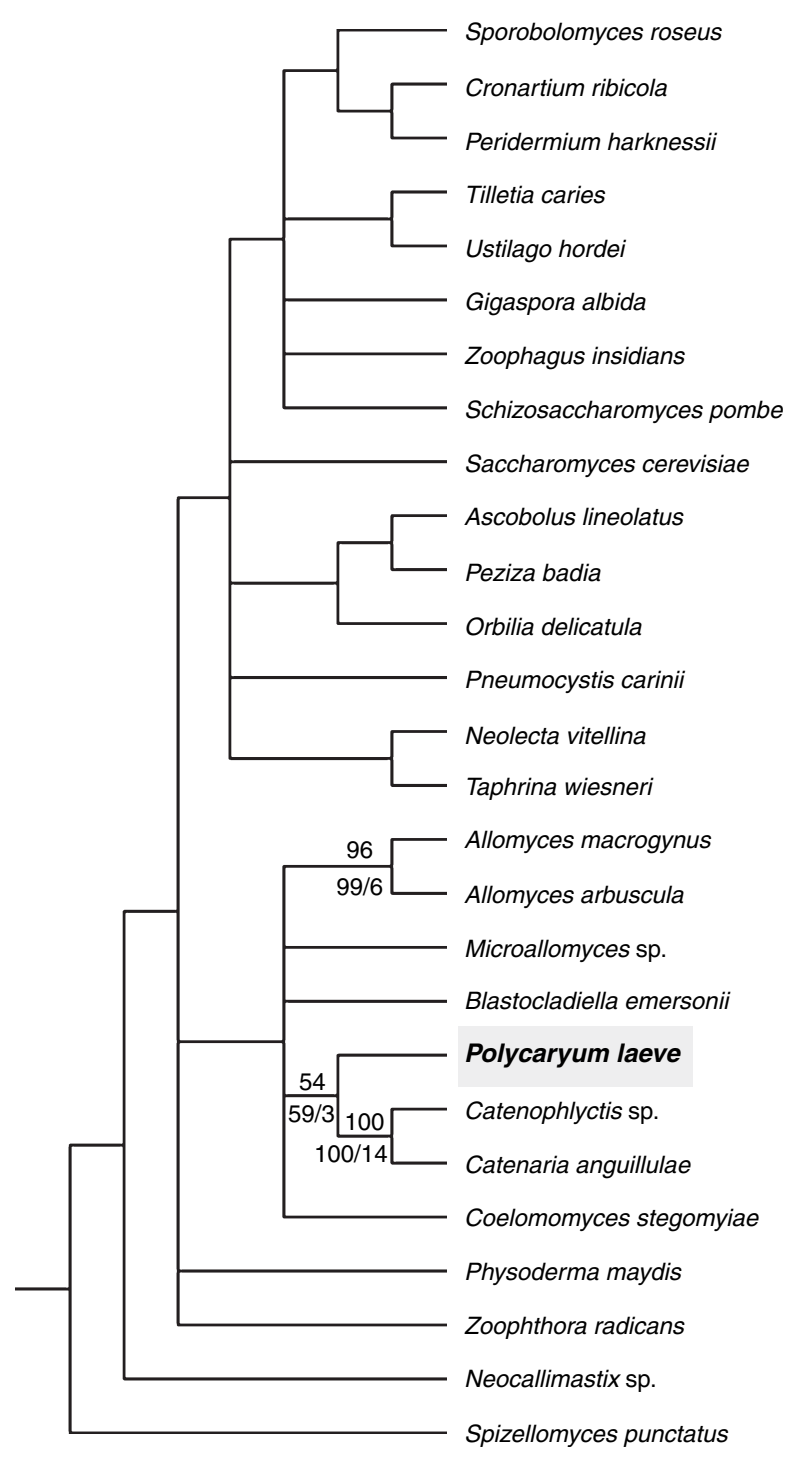

Fig. 8 Results of phylogenetic analyses. Strict consensus tree of the two most parsimonious trees found through maximum parsimony heuristic search and the $50 \%$ majority rule consensus of a Bayesian heuristic search. Relevant Bayesian posterior probabilities are shown above the branches. MP bootstrap values and decay constants are shown below the corresponding branch.

Blastocladiales, $P$. laeve was found to be sister to the Catenariaceae, but support for this arrangement was weak (decay index $=3$, bootstrap $=59$, Bayesian posterior probability $=54$ ), and inconsistent with a ML tree, which grouped $P$. laeve with $C$. stegomyiae (data not shown). There was low support for the MP trees over alternative topologies of the Blastocladiales. The variability in topologies may be due to the short lengths of the sequences (947 bp) and the difficulty in aligning the INDEL-rich regions.

\section{Discussion}

Individual and population effects of infection

Although $P$. laeve has not been recorded previously in North America, we found widespread, often highly prevalent infections by this pathogen in numerous Wisconsin lakes. We confirmed these observations not only through gross pathology, but also by the development of a PCR primer that was validated on infected and uninfected hosts from 20 different lakes. A combination of field, experimental and histological data indicate that $P$. laeve is highly pathogenic in its Daphnia host. In Allequash Lake, $P$. laeve infection was extremely prevalent in D. pulicaria populations (up to $80 \%$ ), particularly during late winter and early spring. Among >2000 examined Daphnia, infection was associated with parasitic castration, with $<1 \%$ of infected females supporting eggs. These results were corroborated by a life table study, which indicated that infection caused reproductive castration, reduced growth, and increased mortality relative to uninfected Daphnia. Infections advanced in intensity during the study and no individuals recovered from infection. Histopathological observations confirmed the degeneration of reproductive and muscular tissues in association with infection. Correspondingly, we observed marked reductions ( $>2$ orders of magnitude) in the population density of $D$. pulicaria in Allequash Lake immediately following epidemics. Although we cannot rule out other sources of mortality (e.g. food limitation), the most severe population decline occurred in March, a time when fish predation is minimal and algal food supplies are abundant. Subsequent recovery of the $D$. pulicaria population without $P$. laeve suggests that infection contributed to the observed decline, either directly or indirectly. Parasite transmission (via zoospore release) requires the death of the host, suggesting that mortality is a consistent consequence of $P$. laeve infection.

\section{Partial life cycle of Polycaryum laeve}

In Wisconsin, $P$. laeve is largely host specific to D. pulicaria. Infections were rarely observed in other cladocerans, and only during periods when preval- 
ence of the parasite was high in populations of D. pulicaria (i.e. 'spillover' infections). Evidence for horizontal transmission may be inferred from the rarity of infected individuals with eggs and the overall increase in prevalence with host size class. Larger individuals may be more likely to become infected either because of their age, increased filtration rate relative to smaller (younger) Daphnia, or because of a necessary incubation period before infection becomes visible. Attempts to raise offspring from the few infected Daphnia with eggs yielded only uninfected neonates, indicating that vertical transmission is unlikely.

The complete life cycle of $P$. laeve and the conditions necessary for transmission remain conjectural. Initial attempts to transmit or culture $P$. laeve failed, suggesting that the parasite has an indirect life cycle involving additional host species or free-living stages. In support of this possibility, species in the closely related blastocladialean genus Coelomomyces use mosquito larvae as definitive hosts and copepods as intermediate hosts (Whisler, Zebold \& Shemanchuk, 1975; Whisler et al., 1999). Within the mosquito host the coenocytic, weakly-branched thallus of Coelomomyces gives rise to large numbers of thick-walled sporangia (Whisler et al., 1975). Meiosis occurs in the resting spores, releasing zoospores that infect copepods and develop into unwalled gametangia. Gametes, which are uniflagellate and microscopically indistinguishable from zoospores, fuse to form a biflagellate zygote that infects a new, larval mosquito host.

The portion of the life cycle of $P$. laeve occurring in $D$. pulicaria could be analogous to either the mosquito $(2 \mathrm{~N})$ or copepod $(1 \mathrm{~N})$ stage of Coelomomyces. If the thalli in Daphnia are diploid zoosporangia, then zoospores might be infectious to another host species or encyst in lake sediments, and the bi- and multiflagellated stages that we observed would reflect irregular cleavage during zoosporogenesis. Alternatively, if what we have called zoosporangia are actually gametangia, the haploid isogametes (cf. zoospores) could fuse to form biflagellated zygotes and infect an alternate host; this interpretation would explain the pairing and clumping behaviour that we observed. Our preliminary results indicating a positive PCR amplification for cyclopoid copepods and a single Chaoborus larva may be interpreted as support for a multi-host life cycle for $P$. laeve, but this requires further verification.

\section{Taxonomic and phylogenetic position of Polycaryum}

The stages of $P$. laeve observed in D. pulicaria were remarkably similar to those described by Stempell (1903), although his observations were primarily from fixed material in D. longispina. Whereas Polycaryum was previously considered a member of the Haplosporidia (Stempell, 1903; Green, 1974; Radek \& Herth, 1999), based on our TEM observations of the zoospores and our molecular sequencing results, we transfer $P$. laeve to the Blastocladiales (Chytridiomycota) and designate Stempell's figures [1903, Archiv für Protistenkunde, 2: Tafel (Plate) IX, Figs 1-27] as the appropriate lectotype. Further, we designate collection Allequash Lake 26 June 2003 as the epitype of $P$. laeve. The epitype material is deposited at the New York Botanical Garden as 00705250. We cannot assign $P$. laeve to a specific family within Blastocladiales without additional molecular data, particularly from other pathogenic members of the Blastocladiales.

The first species appropriately described for this genus was P. branchipodianum Stempell, 1902, a parasite of fairy shrimp (Branchipus grubei; Branchiopoda, Anostraca) that forms an ornamented resting spore. This ornamented resting spore, which somewhat resembles the $2 \mathrm{~N}$ resting spores of Coelomomyces spp. and the lipid-globule configuration that dominates sporangia of $P$. laeve, indicates that this fungus also is a member of the Blastocladiales. Therefore, we designate Figs 1-8 [Stempell, 1902 Zoologische Jahrbucher. Abteilung für Systematik, Geographie und Biologie der Tiere 15: Tafel (Plate) 31, Figs 1-8] as the lectotype for $P$. branchipodianum and place it in the Blastocladiales. Because P. branchipodianum was published previous to $P$. laeve, we consider it as the type species of the genus. Two other species, Polycaryum ecdyonuris and P. legeri, were described as parasites of mayflies (Weiser, 1977, 1984). Little information is available on these species and their taxonomic affinities remain uncertain (J. Weiser, personal communication).

\section{Implications}

Fungal pathogens can cause marked changes in the population dynamics of many aquatic invertebrates, including copepods, midges and crayfish (Green, 1974; Burns, 1979; Redfield \& Vincent, 1979; Martin, 
1981, 1984; Reynolds, 1988). To the best of our knowledge, however, $P$. laeve is the first recorded chytrid disease of Daphnia. Given the epidemic outbreaks of $P$. laeve and its pathogenicity in Daphnia, we believe that the parasite has a significant regulatory effect on host population dynamics. In Allequash Lake, for example, the most severe epidemic in March was followed by a catastrophic (99\%) decline in Daphnia population density. This occurred well before the expected seasonal decline in Daphnia, which is typically around late June or early July in Allequash (see Fig. 2). Although $P$. laeve appears to be a relatively recent arrival in Allequash Lake, we have subsequently recorded infections from $>25$ lakes in Wisconsin, indicating that this parasite is enzootic in Wisconsin lakes. Given the keystone importance of Daphnia in lake food webs, epidemics of $P$. laeve could have ecosystem-scale consequences under certain conditions. Large-bodied Daphnia such as $D$. pulicaria are effective grazers of phytoplankton and can have important effects on nutrient cycling, primary production and water clarity (e.g. Carpenter et al., 1987). Correspondingly, D. pulicaria is an important food resource for many young-of-the-year and planktivorous fishes; epidemics of $P$. laeve could therefore lead to shifts in food web structure or fish production. Additional research should focus on: (i) the long-term effects of $P$. laeve infection on Daphnia populations, (ii) how environmental factors influence $P$. laeve epidemics, (iii) completion of the parasite life cycle and (iv) field and modelling efforts aimed at evaluating the consequences of infection for lake food webs, including both fish production and water clarity.

\section{Acknowledgments}

We are indebted to the many individuals who provided assistance with sampling and logistical support, including Steve Carpenter, Tim Kratz, James Rusak, Scott van Egeren and the UW Trout Lake Station staff. We would also like to thank Barbara Benson and the UW Zoology Museum, which archives zooplankton samples for the North Temperate Lakes LTER project. James Ellwein and Julia Logeman provided invaluable assistance with sample processing, Philip Oshel dedicated his time and energy for scanning electron microscopy and Randy Massey offered his expertise in transmission electron microscopy. Chris Lucarotti offered valuable assistance with interpretation of micrographs. Kersten Wheeler provided histological support at VIMS. This project was funded, in part, by grants from the National Science Foundation (DEB-0411760, DEB0217533, DEB-0083545, DEB-9978094), an NSF Graduate Research Fellowship to PTJJ, the Anna Grant Birge Foundation and the Research Experience for Undergraduates (REU) programme.

\section{References}

Barr D. J. S. (1990) Phylum Chytridiomycota. In: Handbook of Protoctista, (Eds Margulis L., Corliss J. O., Melkonian M. \& Chapman D. J.), pp. 454-466. Jones and Bartlett Publishers, Boston.

Barr D. J. S. \& Désaulniers N. L. (1987) Allochytridium luteum n. sp.: morphology, physiology and zoospore ultrastructure. Mycologia, 79, 193-199.

Bengtsson J. \& Ebert D. (1998) Distribution and impacts of microparasites on Daphnia in a rockpool metapopulation. Oecologia, 115, 213-221.

Bittner K., Rothhaupt K.O. \& Ebert D. (2002) Ecological interactions of the microparasite Caullerya mesnili and its host Daphnia galeata. Limnology and Oceanography, 47, 300-305.

Bower S. M., Carnegie R. B., Goh B., Jones S. R. M., Lowe G. J. \& Mak M. W. S. (2004) Preferential PCR amplification of parasitic protistan small subunit rDNA from metazoan tissues. Journal of Eukaryotic Microbiology, 51, 325-332.

Brambilla D. J. (1983) Microsporidiosis in a Daphnia pulex population. Hydrobiologia, 99, 175-188.

Burns C. W. (1979) Fungal parasitism in a copepod population: the effects of Aphanomyces on the population dynamics of Boeckella dilatata Sars. Journal of Plankton Research, 7, 201-205.

Burns C. W. (1989) Parasitic regulation in a population of Boeckella hamata Brehm (Copepoda: Calanoida). Freshwater Biology, 21, 421-426.

Carnegie R. B., Meyer G. R., Blackbourn J., CochennecLaureau N., Berthe F. C. J. \& Bower S. M. (2003) Molecular detection of the oyster parasite Mikrocytos mackini, and a preliminary phylogenetic analysis. Diseases of Aquatic Organisms, 54, 219-227.

Carpenter S. R., Kitchell J. F., Hodgson J. R., Cochran P. A., Elser J. J., Elser M. M., Lodge D. M., Kretchmer D., He X. \& von Ende C. (1987) Regulation of lake primary productivity by food-web structure. Ecology, 68, 18631876.

Decaestecker E., De Meester L. \& Ebert D. (2002) In deep trouble: habitat selection constrained by multiple 
enemies in zooplankton. Proceedings of the National Academy of Sciences (USA), 99, 5481-5485.

Duffy M. A., Hall S. R., Tessier A. J. \& Huebner M. (2005) Selective predators and their parasitized prey: are epidemics in zooplankton under top-down control? Limnology and Oceanography, 50, 412-420.

Ebert D. (1995) The ecological interaction between a microsporidian parasite and its host Daphnia magna. Journal of Animal Ecology, 64, 361-369.

Ebert D., Lipsitch M. \& Mangin K. L. (2000) The effect of parasites on host population density and extinction: experimental epidemiology with Daphnia and six microparasites. American Naturalist, 156, 459-477.

Ebert D., Hottinger J.W. \& Pajunen V. I. (2001) Temporal and spatial dynamics of parasites in a Daphnia metapopulation: which factors explain parasite richness? Ecology, 82, 3417-3434.

Fels D., Lee V. A. \& Ebert D. (2004) The impact of microparasites on the vertical distribution of Daphnia magna. Archiv fur Hydrobiologie, 161, 65-80.

Green J. (1974) Parasites and epibionts of Cladocera. Transactions of the Royal Society of London, 32, 417-515.

Huelsenbeck J. P. \& Ronquist F. (2001) MrBayes: Bayesian inference of phylogeny. Bioinformatics, 17, 754-755.

Humason G. L. (1979) Animal Tissue Techniques, 4th edn. WH Freeman \& Co, San Francisco.

Kilham S. S., Kreeger D. A., Lynn S. G., Goulden C. E. \& Hen-era L. (1998) COMBO: a defined freshwater culture medium for algae and zooplankton. Hydrobiologia, 377, 147-159.

Luna L. G. (1968) Manual of Histologic Staining Methods of the Armed Forces Institutes of Pathology, 3rd edn. McGraw-Hill Book Company, New York.

Maddison D. R. \& Maddison W. P. (2002) MacClade. Version 4.05. Sinauer, Sunderland, Massachusetts.

Martin W. W. (1981) The natural regulation of midge populations by aquatic fungi. Virginia Journal of the Elisha Mitchell Society, 97, 162-170.

Martin W. W. (1984) The dynamics of aquatic fungi parasitic in a stream population of the midge, Chironomus attenuatus. Journal of Invertebrate Pathology, 44, 36-45.

Radek R. \& Herth W. (1999) Ultrastructural investigation of the spore-forming protist Nephridiophaga blattellae in the Malpighian tubules of the German cockroach Blattella germanica. Parasitology Research, 85, 216-231.

Redfield G.W. \& Vincent W. F. (1979) Stages of infection and ecological effects of a fungal epidemic on the eggs of a limnetic copepod. Freshwater Biology, 9, 503-510.
Reynolds J. D. (1988) Crayfish extinctions and crayfish plague in central Ireland. Biological Conservation, 45, 279-285.

Stempell W. (1902) Uber Jahrbucher Polycaryum branchipodianum n. g., n. sp. Zoologische. Abteilung für Systematik, Geographie und Biologie der Tiere, 15, 591-596. and Tafel, 31.

Stempell W. (1903) Beiträge zur Kenntnis der Gattung Polycaryum. Archives for Protistenkunde, 2, 349-363.

Stirnadel H. A. \& Ebert D. (1997) Prevalence, host specificity and impact on host fecundity of microparasites and epibionts in three sympatric Daphnia species. Journal of Animal Ecology, 66, 212-222.

Swofford D. L. (2002) PAUP*: Phylogenetic analysis using parsimony (*and other methods). Version 4. Sinauer, Sunderland, Massachusetts.

Torgersen T., Karlsbakk E. \& Kaartvedt S. (2002) Deviating vertical distribution and increased conspicuousness of parasitized Calanus. Limnology and Oceanography, 47, 1187-1191.

Weiser J. (1977) An atlas of insect diseases. (Ed. W. Junk), B.V. Publishers, The Hague, Netherlands, 240 pp.

Weiser J. (1984) Ecology of mayfly infections. In: Proceedings of the 4th International Conference on Ephemeroptera. (Eds V. Landa, T. Soldan \& M. Tonner), pp. 291-296. Inst. Entomol., Czech. Acad. Sci., Praha, Czechoslovakia.

Whisler H. C., Zebold S. L. \& Shemanchuk J. A. (1975) Life-history of Coelomomyces psorophorae. Proceedings of the National Academy of Sciences (USA), 72, 693-696.

Whisler H. C., Gabriel B. P., Chanpaisaeng J, Zebold S. L. \& Padua L. E. (1999) Observations on the life cycle of Coelomomyces indicus (Blastocladiales: Coelomomycetaceae) in anopheline mosquitoes from the Philippines and Thailand. Journal of Medical Entomology, 36, 695-701.

Willey R. L., Cantrell P. A. \& Threlkeld S. T. (1990) Epibiotic euglenoid flagellates increase the susceptibility of some zooplankton to fish predation. Limnology and Oceanography, 35, 952-959.

Willey R. L., Willey R. B. \& Threlkeld S. T. (1993) Planktivore effects on zooplankton epibiont communities: epibiont pigmentation effects. Limnology and Oceanography, 38, 1818-1822.

Yan N. D. \& Larsson J. I. R. (1988) Prevalence and inferred effects of microsporidia of Holopedium gibberum (Crustacea: Cladocera) in a Canadian Shield lake. Journal of Plankton Research, 10, 875-886.

(Manuscript accepted 20 December 2005) 